\title{
Local perceptions as a guide for the sustainable management of natural resources: empirical evidence from a small-scale society in Bolivian Amazonia
}

\author{
$\frac{\text { Álvaro Fernández-Llamazares }}{1,3}^{1,2}, \underline{\text { Isabel Díaz-Reviriego }}^{1}, \underline{\text { Maximilien Guèze }}^{1}$, Mar Cabeza $^{2}$, Aili Pyhäläa $^{1,2}$ and $^{\text {Victoria Reyes-García }}$
}

\begin{abstract}
Research on natural resource management suggests that local perceptions form the basis upon which many small-scale societies monitor availability and change in the stock of common-pool natural resources. In contrast, this literature debates whether local perceptions can be effective in guiding the sustainable management of natural resources. With empirical evidence on this matter still highly limited, we explored the role of local perceptions as drivers of harvesting and management behavior in a small-scale society in Bolivian Amazonia. We conducted structured interviews to capture local perceptions of availability and change in the stock of thatch palm (Geonoma deversa) among the Tsimane', an indigenous society of foragers-horticulturalists ( $\mathrm{n}=296$ adults in 13 villages). We analyzed whether perceptions of availability match estimates of abundance obtained from ecological data and whether differences in perception help to explain harvesting behavior and local management of thatch palm. Perceptions of availability of $G$. deversa are highly contingent upon the social, economic, and cultural conditions within which the Tsimane' have experienced changes in the availability of the resource, thus giving a better reflection of the historical, rather than of the ecological, dimensions of the changes undergone. Although local perceptions might fall short in precision when scrutinized from an ecological standpoint, their importance in informing sustainable management should not be underestimated. Our findings show that most of the harvesting and management actions that the Tsimane' undertake are, at least partially, shaped by their local perceptions. This paper contributes to the broader literature on natural resource management by providing empirical evidence of the critical role of local perceptions in promoting collective responses for the sustainable management of natural resources.
\end{abstract}

Key Words: change perceptions; collective action; common-pool resources; local peoples; overharvesting; Tsimane'

\section{INTRODUCTION}

Strong evidence suggests that small-scale societies are capable of designing robust institutional arrangements for managing natural resources sustainably (Ostrom 1999, Agrawal 2001, Basurto et al. 2013). Researchers have documented myriads of systems of communal ownership and collective management of commonpool natural resources (e.g., Ostrom 1990, 2008, Bodin and Crona 2008). These systems rely both on formal and informal institutions and are encoded in different rules, norms, conventions, sanctions, spiritual beliefs, and taboos (Sirén 2006, Luz 2013, Salo et al. 2013).

Besides institutions, the extensive theoretical and empirical research on the management of common-pool natural resources pays particular attention to the role of individuals as decision makers and to the circumstances under which decisions are made (Ostrom 1999, Agrawal 2001, Aswani et al. 2013). Researchers argue that to enable and maintain sustainable management of natural resources, a critical first component is that resource managers hold accurate, relevant, and effective information about the natural resource to be managed, including information on its state, availability, quality, and change (Alessa et al. 2008, Ostrom 2008). For many small-scale societies, a common way to obtain such information is through constant and active monitoring of the status of local resources (Bodin and Crona 2008, McCarthy et al. 2014). Although some authors have emphasized the importance of tapping into scientific knowledge for effective monitoring of resources (Noss et al. 2005, Ostrom 2008), in many parts of the world governance and management decisions regarding natural resources are not based on scientific knowledge, often because of its unavailability (Rist et al. 2010, FernándezLlamazares et al. 2015a). On the contrary, local knowledge and individual perceptions often form the basis upon which many small-scale societies monitor availability and change in natural resources (Maule and Hodgkinson 2002, López-Hoffman et al. 2006). For this reason, local perceptions are considered critical in designing the success of the sustainable management of natural resources among small-scale societies (Oldekop et al. 2012, McCarthy et al. 2014).

In general, local peoples do not base decisions regarding natural resources on conventional cost-benefit analyses as defined by economists (Maule and Hodgkinson 2002). Rather, decisions are based on the accumulation of multiple and diverse sources of information, derived from detailed and rich local knowledge of the environment, cultural values, and/or peer information (LópezHoffman et al. 2006, Alessa et al. 2008). For example, to monitor resource population status, aboriginal fishers in California eyeball the numbers of salmon in upstream migration (Swezey and Heizer 1977), Cree hunters in Canada estimate the amount of goose noise in staging areas (Moller et al. 2004), and indigenous Kichwa in Ecuador count the walking time to the closest stand of Pholidostachys synanthera (Salo et al. 2013).

Perceptions of environmental change can therefore be considered a form of tacit and situated knowledge, reflecting a depth of embodied experience unlikely to be derived through structured and formalized processes (Fazey et al. 2005). On the one hand, perceptions of environmental change are based on factual and direct knowledge or continued observation of biophysical

${ }^{1}$ Institut de Ciència i Tecnologia Ambientals (ICTA), Universitat Autònoma de Barcelona, ${ }^{2}$ Metapopulation Research Centre (MRC), Department of Biosciences, University of Helsinki, ${ }^{3}$ Institució Catalana de Recerca i Estudis Avançats (ICREA) 
phenomena (Gearheard et al. 2010, Orlove et al. 2010). On the other hand, they also encompass embodied experience directly acquired through perceptual information (Leclerc et al. 2013). Given this dual character, the literature has to date interchangeably used the terms "perception" (e.g., Oldekop et al. 2012) and "knowledge" (e.g., Riseth et al. 2011) to refer to accounts of environmental changes reported by small-scale societies. Actually, whether local people's experience of environmental changes can be considered as knowledge or perception is still debated (see Yeh 2015), because many of these perceptions are inherently tacit (i.e., not articulated in a form easily accessible to others; Raymond et al. 2010). Such experiential character echoes the nature of local environmental knowledge, a holistic cumulative body of knowledge, practice, and belief embedded in the culture of a group, including local institutions, and borne from continued periods of observation (Berkes et al. 2000; Gagnon and Berteaux 2009).

In any case, based on such perceptual information (be it theorized or referred to as perception or local knowledge), local resource users often determine whether change merits a certain response, including shifts in management strategies (Oldekop et al. 2012). In some cases, local perceptions of change in the availability of natural resources have led to the adoption of bottom-up selfgoverned arrangements to regulate and/or adjust harvesting activities to safeguard sustainability (e.g., Rudel et al. 2002, Sirén 2006, Salo et al. 2013). However, in other cases, the decreasing availability of natural resources might not be perceived as such and/or internalized as a communal problem, thus weakening possible initiatives of collective action ( $\mathrm{Lu} 2005$, Bodin and Crona 2008). For example, detailed ethnographic reports from various small-scale societies across the tropics show that localized depletion of resources has often led to individuals maximizing their individual foraging efficiency and increasing harvesting effort, despite the potential ecological consequences of such decisions (Alvard et al. 1997, Peres 2000). Such examples show that local perceptions may not always be effective in preventing resource exhaustion and guiding a sustainable use of natural resources (Lu 2001, Peres 2010, Fernández-Llamazares et al. $2015 b)$.

Why is it that local perceptions of availability and change in the stocks of natural resources do not always result in fostering their sustainable management? Empirical evidence on this matter is still highly ambiguous, largely because of a considerable lack of research exploring local perceptions as drivers of harvesting and management behavior in the context of specific natural resource challenges. To fill this gap, we investigated local perceptions of availability and change in the stocks of thatch palm Geonoma deversa (Poit. Kunth) among the Tsimane', a small-scale society in Bolivian Amazonia. Thatch palm is a cultural keystone species for the Tsimane' (sensu Garibaldi and Turner 2004) in that it has great symbolic value and cultural importance for Tsimane' identity (Huanca 2008).

In the present work, we use the terms "availability perception" and "change perception" as leading analytical concepts. Availability perception is defined as the individual evaluation of the available stocks of a given resource at the present moment, whereas change perception is defined as the individual evaluation of change in the stocks of a given resource over time. Following Verweij et al. (2010), both concepts are defined in the wider context of observation and successive evaluation, interpretation, and appreciation of all information captured, i.e., both from personal experience and other sources. It is important to note that we consider perceptions as part of a larger system of knowledge that is developed locally, passed down through generations, and integrated with both local values and information from external sources (Berkes 2009), as well as being experiential and based on the belief systems (Ingold and Kurtilla 2000, FernándezLlamazares et al. 2015a). In absence of written records, perceptions of the status and change of natural resources are captured in local environmental knowledge, which is stored, revived, and transmitted as social memory (Berkes et al. 2000, Barthel et al. 2013).

Our research had three specific objectives: (1) to describe the Tsimane' management regime of $G$. deversa as currently practiced, (2) to examine whether there is concordance between local perceptions of $G$. devers $a$ availability and estimates of availability obtained from ecological data in the Tsimane' Territory, and (3) to analyze whether different perceptions of $G$. deversa availability and change explain harvesting behavior and local management in general. On the basis of our results, we contribute to the broader literature on natural resource management by providing evidence of the critical role of local perceptions in promoting collective responses for the sustainable management of natural resources.

\section{CASE STUDY}

The Tsimane' are a foraging-horticulturalist society of about 12,000 people living in the Department of Beni, Bolivian Amazonia (see Huanca 2008). We conducted research in 13 villages of the Tsimane' Territory, an area of approximately 400,000 hectares lying between the eastern foothills of the Andes and the flooded pampas of Moxos (Fig. 1). The area studied is communally owned by the Tsimane' (Reyes-García et al. 2014). Most of the Tsimane' territory is covered by terra firme rainforests with a high semideciduous canopy reaching $40 \mathrm{~m}$ (Guèze et al. 2014a).

Fig. 1. Map of the study area.

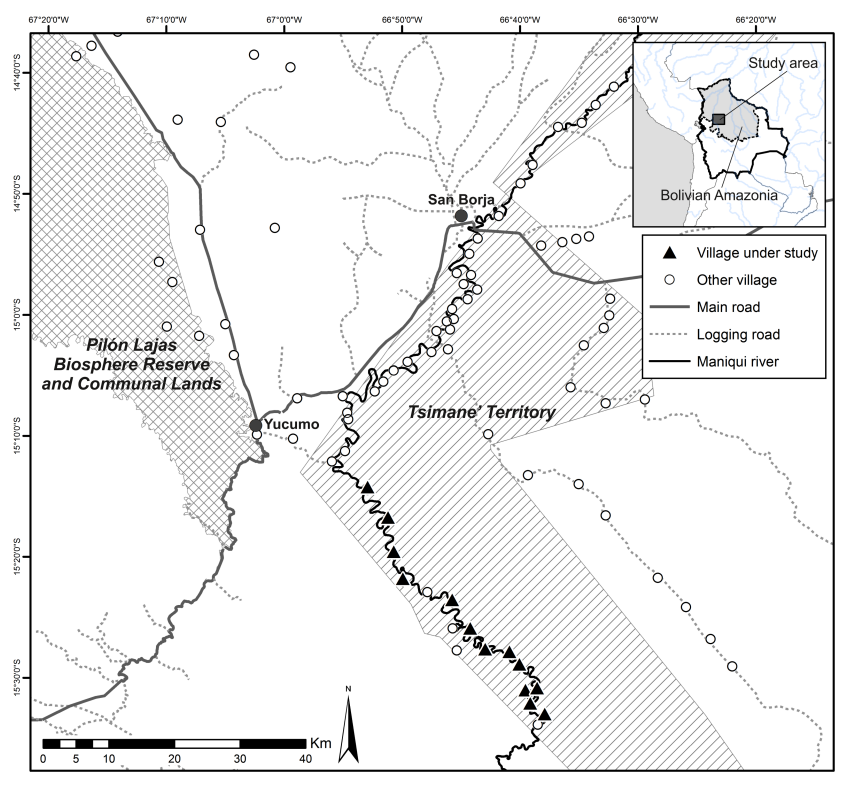




\section{Thatch palm Geonoma deversa}

Geonoma deversa (known as jatata in Spanish or cajtafa in Tsimane') is an understory palm species found in the lowland oldgrowth forests of Bolivian Amazonia. It has multiple stems (3-30 per plant) and can produce new stems from basal shoots even after 1 or several stems are cut (Paniagua-Zambrana 2005). Some of its characteristic features are its medium size (up to 3 meters tall), its trifoliate leaves (up to $75 \mathrm{~cm}$ long), and its flower pits (Moraes 1999).

G. deversa is largely distributed across the humid forests of the Amazonian Occidental Basin, including the Bolivian lowlands, although the density of the species varies from one site to another (Moraes 1999). The species has a patchy distribution (i.e., it typically grows in isolated, locally dense population patches), with densities ranging from 70 to 2000 individuals per hectare (Ergueta et al. 2006). It also has highly specific habitat requirements, restricted to humid terra firme old-growth forests mostly in the upper flanks of ridges, in well-drained soils (Paniagua-Zambrana 2005). Such stands are locally known as thatch palm groves, and they provide rich habitat for wildlife. In the Tsimane' Territory, $G$. deversa is naturally abundant in the upper Maniqui River, but scarcer in the moist forests downstream of the Maniqui (Ergueta et al. 2006).

\section{Traditional uses of $G$. deversa among the Tsimane'}

$G$. deversa leaves are traditionally harvested for the use of thatch roofing of Tsimane' houses (Reyes-García 2001). Thatch palm harvesting occurs year-round and is usually performed in collective expeditions involving all members of a household including men, women, and children or, in many cases, several households from the same clan or extended family. These harvests are important social activities that provide links to the ancestors, and to Tsimane' land and cultural identity (Huanca 2008). G. deversa stems are short, usually 1-3 m, such that their fronds can easily be harvested without felling the whole plant (PaniaguaZambrana 2005). The fronds are then carried back to the village, where they are woven into roof panes by both men and women. On average, 500 thatch palm panes, with approximately 300 leaves each, are needed for roofing a surface of $100 \mathrm{~m}^{2}$ (PaniaguaZambrana 2005).

Tightly woven thatch palm panes provide a leak-free and burntolerant roof that can last up to 20 years before needing replacement (Moraes 1999). Although the leaves of other palm species are also used by the Tsimane' for the thatching of their houses (see Reyes-García 2001 for an exhaustive list of palm species used), G. deversa is by far the most valued species by the Tsimane' because of its exceptionally longer durability. G. deversa roofs of the Tsimane' houses are among the most characteristic features of the communities along the Maniqui River (Pauly 1928). Although tin roofs have begun to replace thatch roofs in some villages closer to town, $G$. deversa continues to be highly popular because of the coolness it provides. The cultural importance of $G$. deversa can be seen also in that it appears in many Tsimane' oral stories and traditions, including the Tsimane' creation myth (Huanca 2008).

\section{History and importance of thatch palm trade in the Tsimane' Territory}

Thatch palm not only serves an important function in local livelihoods, but also has long been an important cash product, with demand from urban and periurban areas. It has thus formed the basis of a specific market, with traders specialized in sourcing, transporting, and commercializing the product. Ethnographers situate the arrival of the first traders to the Tsimane' Territory around the 1950s (Riester 1993, Huanca 2008), but it was not until the early 1980 s that the demand for the species experienced a regional boom (Guèze et al. 2014b). Being one of the cheapest alternatives to corrugated iron, thatch palm panes (including $G$. deversa as well as other palm species) became highly valued throughout the Bolivian lowlands, particularly in touristic venues, because of the rustic look of these panes. Thus, it is hardly surprising that the commercialization of $G$. deversa became also a primary source of income for the Tsimane' (Godoy et al. 2001). Today, G. deversa is the most important nontimber product traded by the Tsimane', often used also as currency in barter when obtaining commercial products from traders (Luz 2013).

Traders acting as intermediaries are usually the ones responsible for the commercialization of $G$. deversa in the market town of Yucumo (Fig. 1). These traders regularly visit Tsimane' villages in the upstream part of the Maniqui, where they deliver commercial items (e.g., salt, alcohol) en route upriver in exchange for future deliveries of woven thatch palm panes that they agree to collect during their trip downriver. If the deliveries of thatch palm are not ready when the traders return to the villages, the debts grow higher through the application of interest rates. Ethnographic reports show that traders often intimidate and exploit the Tsimane', and also take advantage of their limited mathematical skills to cheat them when making deals, further indebting them (Reyes-García 2001, Huanca 2008).

Despite attempts to overturn the unfair productive system around thatch palm, even nowadays the barter with non-Tsimane' traders as described above continues to be the norm in the area. In the last years, the mounting extractive pressure of $G$. deversa, driven by market demand, has led to the region's thatch palm groves becoming ever more scarce, particularly in the vicinity of Tsimane' settlements (Moraes 1999). Apparently, during the 1970-1980s, the harvesting of $G$. deversa did not cause a severe negative impact on the species, because the gathering was moderate and the palms regenerated quickly (Huanca 2008). However, following the regional boom of the $1980 \mathrm{~s}$, thatch palm has started to show clear signs of local depletion because of overharvesting (Ergueta et al. 2006, Guèze et al. 2014b).

\section{METHODS}

We conducted fieldwork between January 2012 and November 2013 in 13 villages located in the upper Maniqui River where, according to Ergueta et al. (2006), G. deversa is present. To carry out this study, we first obtained free prior and informed consent from each village and individual participating in the study, as well as the agreement of the Tsimane' political organization, the Great Tsimane' Council (Gran Consejo Tsimane'). In addition, this research adheres to the Code of Ethics of the International Society of Ethnobiology.

All adults (defined as people age 16 years or older) in the villages were invited to participate in the research. We encouraged both women and men to participate in the study with the aim of ensuring equal representation in the sample. Overall, we had a participation rate of more than $80 \%$ of the adult population of each village, across all villages. Our analysis drew on three 
Table 1. Summary descriptive statistics of the sample composition.

\begin{tabular}{|c|c|c|c|c|c|c|c|c|}
\hline \multirow[t]{2}{*}{ Objective } & \multirow[t]{2}{*}{ Data collection } & \multirow{2}{*}{$\begin{array}{l}\text { No. of } \\
\text { villages }\end{array}$} & \multirow[t]{2}{*}{ Variable } & \multicolumn{5}{|c|}{ Descriptive statistics } \\
\hline & & & & $n$ & Mean & SD & Min & $\operatorname{Max}$ \\
\hline \multirow[t]{2}{*}{$\begin{array}{l}\text { To describe the Tsimane' management regime of } \\
\text { G. deversa as currently practiced }\end{array}$} & $\begin{array}{l}\text { Field visits and } \\
\text { open-ended } \\
\text { interviews }\end{array}$ & 3 & Age & 15 & 35.00 & 10.38 & 21 & 49 \\
\hline & & & Sex & \multicolumn{5}{|c|}{$\begin{array}{l}10 \text { men }(66.67 \%) \\
5 \text { women }(33.33 \%)\end{array}$} \\
\hline \multirow{3}{*}{$\begin{array}{l}\text { To examine whether there is concordance } \\
\text { between local perceptions of } G \text {. deversa } \\
\text { availability and estimates of availability obtained } \\
\text { from ecological data in the Tsimane' Territory }\end{array}$} & $\begin{array}{l}\text { Structured } \\
\text { interviews }\end{array}$ & 13 & Age & 296 & 38.35 & 17.80 & 14 & 88 \\
\hline & & & Sex & \multicolumn{5}{|c|}{$\begin{array}{l}142 \text { men }(47.97 \%) \\
154 \text { women }(52.03 \%)\end{array}$} \\
\hline & Focus groups & 2 & $\begin{array}{l}\text { Age } \\
\text { Sex }\end{array}$ & $\begin{array}{l}16 \\
9 \text { me } \\
7 \text { wo }\end{array}$ & $\begin{array}{l}36.53 \\
6.25 \%) \\
(43.75 \%)\end{array}$ & 15.58 & 19 & 70 \\
\hline \multirow{2}{*}{$\begin{array}{l}\text { To analyze whether different perceptions of } G \text {. } \\
\text { deversa availability and change explain } \\
\text { harvesting behavior and local management in } \\
\text { general }\end{array}$} & $\begin{array}{l}\text { Semistructured } \\
\text { interviews }\end{array}$ & 2 & Age & 97 & 40.07 & 20.32 & 16 & 84 \\
\hline & & & Sex & \multicolumn{5}{|c|}{$\begin{array}{l}53 \text { men }(54.64 \%) \\
44 \text { women }(45.36 \%)\end{array}$} \\
\hline
\end{tabular}

different sources of information, each one addressing one of the three objectives of the work.

\section{Ethnographic description of the Tsimane' management regime of G. deversa}

Despite the number of works already describing the different domains of Tsimane' forest management practices (e.g., Godoy et al. 2001, Reyes-García 2001, Luz 2013), explicit accounts of rules regulating access, use, and management of $G$. deversa are rare. We collected qualitative ethnographic information, complemented with participant observation in thatch palm harvesting expeditions. Overall, we conducted eight field visits to different thatch palm groves, accompanying different Tsimane' families in their harvesting of $G$. deversa (see Table 1 for descriptive statistics of the sample). In each visit, we carefully observed the actual harvesting technique. Once the harvest was performed, and before starting the way back to the village, we asked informants to explain the norms and practices related to the management of the species. Such in situ open-ended interviews lasted 15 to 30 minutes each, during which we took detailed field notes. We used the responses given and our field observations to inform the research design and to contextualize results from quantitative data collection methods.

\section{Measurement and validation of local perceptions of $G$. deversa change and availability}

To measure local perceptions of $G$. deversa change and availability, we conducted structured interviews with 296 adults ( $\geq 16$ years old) in 13 villages (Table 1). Ethnographic evidence indicates that the Tsimane' perceive $G$. deversa availability in terms of walking distance (Fernández-Llamazares et al. 2014). Owing to the fact that $G$. deversa grows mostly on ridges and generally far from villages, the Tsimane' have to walk several hours, often climbing pronounced slopes, to reach the closest thatch palm groves Carrying the harvests of up to $20 \mathrm{~kg}$ back to their villages is also no easy feat. Thus, when asked about how much available $G$. deversa there is in the area, their answers generally refer to the walking time to the closest thatch palm grove.

To measure the individual perception of thatch palm availability, we asked about the amount of time that a person has to walk to reach the closest thatch palm grove (see Appendix 1). Based on previous research in the area, we transformed the time reported to kilometers at an average rate of $2.36 \mathrm{~km} / \mathrm{h}$ (Luz 2013). To measure individual perceptions of thatch palm change, we followed a methodology used previously (see FernándezLlamazares et al. 2015b), asking individuals about perceived baselines versus the present state. We used the informant's childhood (i.e., the decade of birth [DOB]) as an individual baseline. We first asked how long they had to walk to reach the closest thatch palm grove at the present time (availability). We then asked how long they had to walk at their DOB (baseline). We transformed both times perceived into walking distances. We then obtained a surrogate measure of change perceived by each individual, comparing the current perceived walking distance with the perceived situation in the DOB.

Owing to the fact that clocks and watches are still quite inaccessible to most Tsimane', the measure of how long it takes someone walk to reach the closest thatch palm grove is probably flawed. To assess the magnitude of the error, in each of the eight expeditions to gather thatch palm, we measured the time invested in walking until reaching the closest thatch palm grove. Upon arrival, we asked informants to estimate how much time they had walked. Results suggest that people interviewed are able to intuitively assess time with relative accuracy. Although all 
estimates were biased (ca. $\pm 15 \%$ ), the bias was similar between villages. So even if the temporal perceptions reported are actually flawed, the level of flaw is most certainly similar in all villages, thus not altering substantially our estimation results.

We also obtained ecological estimates of the availability of the species. First, from 2008 to 2012, a group of researchers carried out a project of participatory mapping of Tsimane' land use (Reyes-García et al. 2012). The team conducted communal workshops in the Tsimane' Territory where villagers sketched maps that included land-use features, such as thatch palm groves. Over the days following the workshop, researchers and village guides covered each village area on foot taking Global Positioning System (GPS) readings of all the thatch palm groves. The data from the sketch maps and GPS readings were later processed in a geographic information system (GIS), providing the most extensive distribution map available for $G$. deversa in the Tsimane' Territory. Second, as part of a floristic inventory from another project (see Guèze et al. 2014a for more details), we noted the presence of $G$. deversa in 48 0.1-ha old-growth forest plots established in the territory of six Tsimane' villages (eight plots per village) to cross-verify that $G$. deversa was abundant in the areas catalogued as "thatch palm groves."

Drawing on the combination of both data sets and with the aid of GIS software, we could obtain a measure for the average distance to the closest thatch palm grove for each of the study villages (Fig. 1). In all cases, this distance was calculated from the village school, which the Tsimane' consider their village center, and with the walking route always following already-established trails. To examine whether local perceptions match estimates of the availability of $G$. deversa, we compared the village average measured distance with the village average perceived distance at the present time, i.e., availability perception.

To examine whether changes in the availability of $G$. deversa have taken place at different timescales along the Maniqui River, we ran a series of T-tests comparing the change perceptions of both older and younger individuals (i.e., born before or after 1970) living in villages both closer or farther from the main market town (i.e., fewer or more than $90 \mathrm{~km}$, respectively). To contextualize our results, we also conducted focus group discussions in two of the villages. All in all, 16 adults ( 9 men and 7 women) of different ages (minimum of 19 years and maximum of 70 years) attended the meetings. During the focus groups, we asked participants about the history of thatch palm trade in the area, the first signs of thatch palm depletion, and measures to prevent $G$. deversa overharvesting.

\section{Measurement of the behavior regarding $G$. deversa harvesting and management}

Accurately measuring $G$. deversa harvesting behavior and management decisions requires long periods of continued observation, e.g., to obtain reliable estimates of thatch palm extraction, controlling for seasonal variations. Conducting such detailed longitudinal research in all 13 villages along the upper Maniqui River was beyond the scope of our possibilities. Instead, we chose to focus this aspect of our study on the two potentially most contrasting villages: the one closest to the market town (a one-day canoe trip from Yucumo, Fig. 1) and the one furthest from the market town (a three-day canoe trip from Yucumo). Because of their differences in distance from, and access to, the nearest market town, visits by thatch palm traders also differ drastically between the two villages. For instance, although traders have quite regularly visited the closer village for the last 40 years, their continued presence is relatively more recent in the isolated village. We interviewed a total of 97 adults ( $\geq 16$ years old) in the two villages about individual behavior regarding $G$. deversa harvesting and management (see Table 1 for descriptive statistics of sample composition).

With regard to individual behaviors in thatch palm harvesting and management, we used different quantitative methods (see Appendix 1). First, individual harvesting behavior was measured with two standard proxies: (1) number of thatch palm panes produced and (2) thatch palm productivity (panes/hour), both in the course of one year. To collect these data, we used an anthropological technique known as scan observations (ReyesGarcía et al. 2009). Each week, on a randomly selected day, we visited each household in the village and asked the adult(s) present to tell us the amount of $G$. deversa (measured in panes) that they themselves had harvested in the previous two days. Over the course of 12 months, this method generated an average of 23.42 observations per person (standard deviation $=6.73$ ). We also asked those present in the household about the time they had invested in thatch palm harvesting. Based on these figures, we calculated individual thatch palm harvest productivity as the number of thatch palm panes produced per hour invested (panes/ hour).

Individual behavior with regard to thatch palm management was further measured with the help of two standard proxies (see Appendix 1): (1) rule compliance and (2) involvement in informal institutions. To assess rule compliance, we created an index (ranging from 0 to 3 ) that captured the interviewee's self-reported degree of respect toward Tsimane' rules regulating the harvesting of G. deversa. This index, adapted from Luz (2013), was based on responses to three binary questions; thatch palm harvesters could respond either that they adhered (1) or not (0) to the specified set of management norms or rules. The questions included three important aspects of management of the palm: (1) respect for the norms regarding harvesting intensity, (2) respect for the rules regulating no-take areas, and (3) respect for the thatch palm groves owned by other households. Thus, the resulting score comprises the number of times that the person reported rule compliance. With regard to individual involvement in informal institutions, attendance at the three meetings held in each village during JuneAugust 2012 was used as a proxy measure. Because village meetings are one of the most important fora for addressing and discussing intravillage and intervillage conflicts around use, access, and management of thatch palm groves, our proxy is a directly relevant measure of involvement in collective action with regard to the management of $G$. deversa.

We then ran a series of ordinary-least-square and Poisson regressions to test the association between individual harvesting and management behavior on the one hand and individual perceptions of $G$. deversa availability and change on the other. All regressions were carried out at the village level to compare the villages closest to and furthest from the market town, included controls for age and sex, and were clustered based on the household of the informants. Statistical analyses were performed with Stata 12.1 (StataCorp 2011). 


\section{RESULTS AND DISCUSSION}

\section{Tsimane' management regime of $G$. deversa}

The Tsimane' have legally held communal land titles since 1996, although the land demarcation process is yet to be finalized (Reyes-García et al. 2014). In fact, the Tsimane' do not traditionally adhere to a system of individual land tenure (Godoy et al. 2001). Natural resources in the Tsimane' Territory, including $G$. deversa, have generally been managed under common-property tenure (sensu Ostrom 1990). Therefore, at least in the past, thatch palm was considered a common-pool resource and regulated through norms of customary access (Reyes-García et al. 2012). Most thatch palm groves in the area are governed by informal norms of access. Results from individual interviews suggest that today the Tsimane' recognize customary ownership of these thatch palm groves; i.e., specific households have access to and rights over specific thatch palm groves, meaning that these groves are for the designated household's use only. These user rights are generally defined according to the Tsimane' customary usufruct system, such that a stand of thatch palm belongs to the household or clan (i.e., group of households) who first harvested it and is generally the property of households with closest access from their houses or agricultural plots, from which they generally trace their trails (Huanca 2008).

Although the Tsimane' Territory is communally owned by all Tsimane' people inhabiting the area and not by specific villages, villages have informal internal boundaries (Reyes-García et al. 2014). Villagers routinely trespass on them in daily activities such as hunting and gathering, but over the years there have been reports of increasing intervillage conflicts when the trespassing involves the collection of resources with a market value such as G. deversa (Reyes-García et al. 2012). For this reason, the political organization representing the Tsimane', the Great Tsimane' Council, has encouraged villages to agree on specific rules to avoid intervillage conflicts with regard to thatch palm harvest. On a series of radiophonic messages, the Tsimane' organization has recurrently recommended that villages zone their thatch palm groves to ensure that harvest agreements and rules are respected. Tsimane' from other villages are expected to seek authorization from the local community for extraction of $G$. deversa on their land. In practice, the villagers are responsible for the control and monitoring of access to the resource, as well as for rule compliance, both for their family thatch palm groves and at the village level. The rules are enforced through a variety of means, including peer pressure, public shaming, or monitoring by informal groups of villagers sporadically surveying the area to prevent land invasions.

Over the years, based on empirical learning, the Tsimane' have developed a number of practices, norms, and techniques to manage $G$. deversa (Guèze et al. 2014b). Concomitant to the high tolerance of $G$. deversa to defoliation (Moraes 1999), the general guiding principle of the Tsimane' when harvesting G. deversa is that at least one third of the leaves of the plant should be left intact (Ergueta et al. 2006). Typically, the Tsimane' first cut off the old leaves, leaving the youngest ones and avoiding damage to the adjacent leaves. The most mature palms (with flowers or fruits; locally known as mother plants) are generally left uncut. In fact, the Tsimane' harvest only leaves from individual palms with stems over $1.5 \mathrm{~m}$ in height (Ergueta et al. 2006). All these techniques have been described as constituting a sustainable form of management, enabling (1) the maintenance of new leaf yield, (2) the safeguard of reproductive individuals as seed bearers, and (3) an increase in light availability for the remaining leaves, avoiding intraclonal shade and taking advantage of the greater photosynthetic capacity of the younger leaves (Chazdon 1991, Moraes 1999).

Interestingly, we did not find any strong evidence of a recognized limit among the Tsimane' as to how much $G$. deversa can be extracted from a thatch palm grove. To our knowledge, at least one village attempted to establish a system of quotas for each family based on the state of the resource, but the regulations came from a development project in the area. That said, there are some informal norms of management, including restrictions on the frequency of harvest, although these tend to be rather vague. The Tsimane' generally plan their $G$. deversa harvesting in two-year cycles. When a zone of a thatch palm grove has been intensively harvested for one year, it is left aside as a no-take area (sensu Salo et al. 2013) for another year, thus allowing the harvested plants to recover. No individual is allowed to cut leaves from no-take areas. Other than these norms and the above-mentioned restrictions on cutting reproductive individuals, we found no active management practices for the enhancement of the resource stock, e.g., by seeding or planting $G$. deversa.

In recent years, different actors, including thatch palm traders, have started to compete over $G$. deversa resources with the local Tsimane' (Huanca 2008). Traders often set their camps close to the thatch palm groves and harvest the resource without the consent of villagers (Huanca 2008). This situation has led to increasing conflicts. Reyes-García et al. (2012) report that among all outsiders in the area (e.g., thatch palm traders, loggers, cattle ranchers, colonist farmers) the Tsimane' tend to have the highest number of conflicts with thatch palm traders. In an open letter directed to the Great Tsimane' Council, some villagers of the upper Maniqui River denounced the situation and requested the expulsion of all outsider thatch palm traders from the Tsimane' Territory (see Fernández-Llamazares et al. 2014). According to locals, restricting palm thatch harvest to only Tsimane' people could reduce the amounts harvested, thus increasing the probability for the maintenance of the resource stock. Although there have been some recent attempts to ban entrance to outsiders, thatch palm traders continue to enter the Maniqui River and harvest $G$. deversa.

\section{Measurement and validation of local perceptions}

Table 2 provides descriptive statistics of the variables measuring change and availability perceptions of $G$. deversa. The average value for our measure of change perception $(3.46 \pm 1.78 \mathrm{~km})$ suggests that most Tsimane' people interviewed perceive changes in thatch palm availability. Many Tsimane' expressed concern over the decreasing availability of $G$. deversa in the area and the potential impacts this might have on their livelihoods. As one informant stated: "Thatch palm is disappearing very quickly and soon we won't even have anything to roof our houses" (woman, age 65, June 2013). However, most Tsimane' interviewed consider that the set of rules restricting the intensity and frequency of thatch palm harvest are efficient in preventing resource exhaustion and ensuring sustainability over time (see also Fernández-Llamazares et al. 2014). The problem for many 
Table 2. Definition and summary statistics of variables measuring perception of Geonoma deversa change and availability among Tsimane' interviewees.

\begin{tabular}{|c|c|c|c|c|c|c|c|}
\hline \multirow[t]{2}{*}{ Variable name } & \multirow[t]{2}{*}{ Description } & \multirow[t]{2}{*}{ Villages $^{\dagger}$} & \multicolumn{5}{|c|}{ Descriptive statistics } \\
\hline & & & $n$ & Mean & $\mathrm{SD}$ & Min & $\operatorname{Max}$ \\
\hline \multirow{3}{*}{$\begin{array}{l}\text { Perception of } G \text {. } \\
\text { deversa } \\
\text { availability }\end{array}$} & $\begin{array}{l}\text { Perceived walking distance to reach the } \\
\text { closest thatch palm grove }(\mathrm{km})\end{array}$ & All $(N=13)$ & 296 & 5.31 & 1.77 & 2.34 & 11.70 \\
\hline & & $\begin{array}{l}<90 \mathrm{~km} \text { from town } \\
(N=6)\end{array}$ & 152 & 5.72 & 1.58 & 2.34 & 9.36 \\
\hline & & $\begin{array}{l}>90 \mathrm{~km} \text { from town } \\
(N=7)\end{array}$ & 144 & 4.88 & 1.85 & 2.34 & 11.70 \\
\hline \multirow[t]{3}{*}{$\begin{array}{l}\text { Perception of } G \\
\text { deversa } \text { change }\end{array}$} & $\begin{array}{l}\text { Difference in the perceived walking } \\
\text { distance to reach the closest thatch palm } \\
\text { grove in the past compared to the perceived } \\
\text { walking distance to reach the closest thatch } \\
\text { palm grove in the present }(\mathrm{km})\end{array}$ & All $(N=13)$ & 296 & 3.46 & 1.78 & 0.00 & 9.36 \\
\hline & & $\begin{array}{l}<90 \mathrm{~km} \text { from town } \\
(N=6)\end{array}$ & 152 & 3.63 & 1.64 & 0.00 & 8.19 \\
\hline & & $\begin{array}{l}>90 \mathrm{~km} \text { from town } \\
(N=7)\end{array}$ & 124 & 3.28 & 1.90 & 0 & 9.36 \\
\hline
\end{tabular}

${ }^{\dagger}$ For village information, see Appendix 2.

Tsimane' is that even if they may comply with the rules, others may not. As a result, palm growth and regeneration are hampered by unsustainable harvesting practices of an increasing number of careless resource users breaking the rules, more importantly the traders. One local elder said, "The traders do not respect our traditional rules: that's why thatch palm is not growing anymore" (man, age 33, April 2013).

Figure 2 shows a comparison between the average villagemeasured walking distance to the closest thatch palm grove and the average village-perceived walking distance, i.e., availability perception. G. deversa is still found in the vicinity of Tsimane' settlements at less than a $3.5-\mathrm{km}$ distance, but only in those villages that are farther away from town, i.e., more than $90 \mathrm{~km}$. In other words, the measured walking distance to the closest thatch palm grove is shorter in villages farther from town than in villages closer to town, most probably because of differences in accessibility also to thatch palm traders (see also Table 2). G. deversa availability estimates derived from ecological sampling match the local perceptions, but only partially. In villages closer to the market town, where $G$. deversa is only found farther away from human settlements, local perceptions match ecological sampling data with relative accuracy. In contrast, the Tsimane' living in villages farther from town seem to overestimate the walking distance to reach the closest thatch palm grove, hence also underestimating G. deversa availability.

The results of the T-tests comparing change perceptions between younger and older individuals both in villages closer to and farther from town suggest that the changes in thatch palm availability happened at different timescales along the Maniqui River (see Table 3). Although older people seem to have witnessed more change in thatch palm availability during their lifetimes, change dates longer back in the villages closer to town than in the ones farther upriver. This aligns well with the fact that the distance to the thatch palm grove is longer in villages closer to town, possibly indicating an advancing wave of harvesting pressure along the
Fig. 2. Mismatch between measured and perceived walking distance to the closest thatch palm groves. The dashed lines show the fitted regression models. The bars indicate the perceived and measured standard error of the mean walking distance.

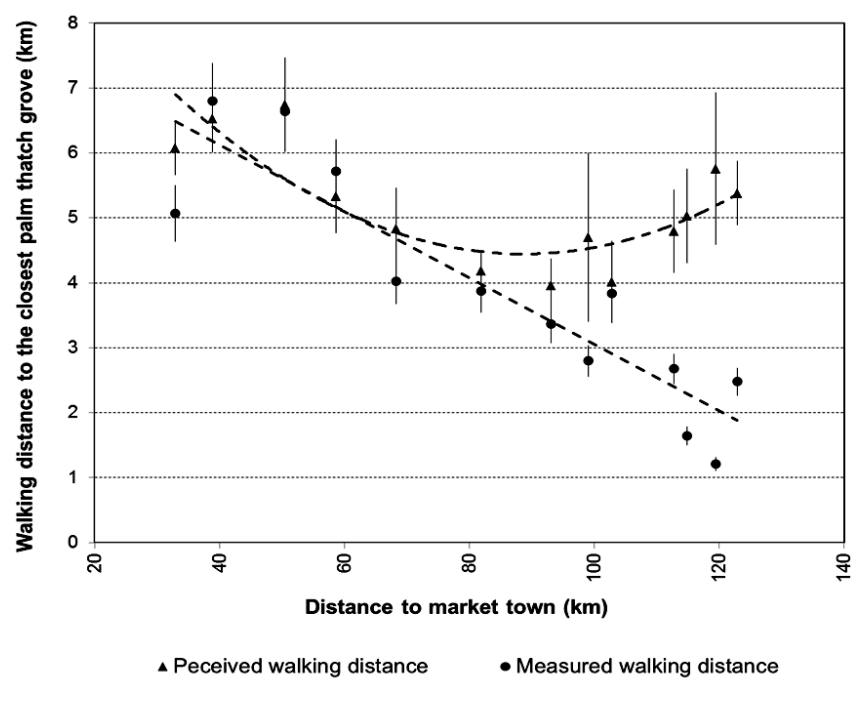

river. Considering that the topographical differences in the area under study are minor and that all the flanks and ridges in the upper Maniqui provide a suitable habitat for the species, as indicated by its presence (see Appendix 2 for more details), such a decreasing trend is most likely the result of overharvesting. Furthermore, in the villages closer to the market town, younger people report significantly greater past walking distances to the closest thatch palm groves than younger people in the villages farther away $(\mathrm{P}<0.01)$, implying a different timescale of changing conditions. Elders provided detailed complementary accounts of 
Table 3. Differences in the perception of change per decade of birth between villages closer and farther from town.

\begin{tabular}{|c|c|c|c|c|c|c|c|c|}
\hline \multirow[t]{2}{*}{ Variable } & \multirow{2}{*}{$\begin{array}{l}\text { Decade of birth of } \\
\text { informants }\end{array}$} & \multicolumn{3}{|c|}{$<90 \mathrm{~km}$ from town } & \multicolumn{3}{|c|}{$>90 \mathrm{~km}$ from town } & \multirow[t]{2}{*}{$P$ value } \\
\hline & & Obs & Mean & SE & Obs & Mean & $\mathrm{SE}$ & \\
\hline \multirow{3}{*}{$\begin{array}{l}\text { Change } \\
\text { perception }\end{array}$} & $1920-1959$ & 35 & 4.023 & 0.276 & 23 & 4.095 & 0.338 & 0.565 \\
\hline & 1960-1999 & 117 & 3.507 & 0.151 & 121 & 3.130 & 0.174 & $0.052 *$ \\
\hline & $P$ value & -- & $0.052 *$ & -- & -- & $0.012^{* *}$ & -- & -- \\
\hline \multirow{3}{*}{$\begin{array}{l}\text { Past walking } \\
\text { distance }\end{array}$} & $1920-1959$ & 35 & 2.229 & 0.261 & 23 & 1.280 & 0.180 & $0.005^{* *}$ \\
\hline & $1960-1999$ & 117 & 2.060 & 0.995 & 121 & 1.679 & 0.117 & $0.007 * * *$ \\
\hline & $\mathrm{P}$ value & -- & 0.233 & -- & -- & $0.079^{*}$ & -- & -- \\
\hline \multirow{3}{*}{$\begin{array}{l}\text { Current walking } \\
\text { distance }\end{array}$} & $1920-1959$ & 35 & 6.251 & 0.275 & 23 & 5.375 & 0.355 & $0.027^{* *}$ \\
\hline & 1960-1999 & 117 & 5.567 & 0.143 & 121 & 4.790 & 0.170 & $0.000^{* * *}$ \\
\hline & $P$ value & -- & $0.012 * *$ & -- & -- & $0.082^{*}$ & -- & -- \\
\hline
\end{tabular}

their temporal perspectives on $G$. deversa changes in the Maniqui River. According to them, in villages farther from town, changes in $G$. deversa availability have been more abrupt and recent, whereas in villages closer to town, changes have been relatively more gradual and long-term because of the continued presence of traders, as illustrated by some of their statements: "While the villages downriver depleted their thatch palm groves long ago, here we have worked to preserve our thatch palm" (woman, age 60, March 2013) and "First they [the traders] ended with the thatch palm near the town and now that it is over, they come here to steal ours" (man, age 91, October 2013).

Our results sit well within the literature showing that perceptions of resource availability need to be interpreted not just from an ecological standpoint, but also as part of the broader context of historical changes, including an understanding of the complex relations between users, resources, and livelihoods (Sirén 2006, Alessa et al. 2008). Like local environmental knowledge, local perceptions of environmental change encompass not only experiential knowledge of the environment, but also symbolic dimensions and/or traditional beliefs (Berkes et al. 2000, Houde 2007). This set of cultural values and beliefs is critical to determine how change is interpreted at the local level (Orlove et al. 2010). If local perceptions of availability of $G$. deversa do not always match ecological estimates of local abundance, this is arguably because perceptions are highly contingent upon the social, economic, and cultural conditions within which the Tsimane' have experienced changes in the availability of the resource. In villages farther from town, where changes in thatch palm availability have been abrupt and perceivable at short-time scales, overstated reports of resource unavailability may probably be signs of increased experience of risk by those Tsimane' whose livelihoods might be significantly threatened by $G$. deversa depletion. This is implicitly manifest in some of the statements made by the villagers upriver: "Very little thatch palm is left nowadays" (woman, age 44, May 2013) and "What will our children sell when our thatch palm is over?" (man, age 40, April 2013). Such risk perception is less manifest in the villages downriver, where there are plenty of alternative sources of monetary income (e.g., sale of timber or agricultural products) because of easier accessibility to the market town.

Additionally, such magnified claims on resource change may be the product of the greater cultural attachment to the resource in villages upriver. It is noteworthy that in some villages upriver, $G$. deversa is sometimes named cajtafa' Tsimanes', which translates to "the thatch palm of the Tsimane' people" (Ergueta et al. 2006), illustrating the strong cultural attachment of these villages to the resource. Because local perceptions are constructed based on arguably more subjective, procedural, spiritual, and sensoryoriented cognitive mechanisms (Moller et al. 2004), it is likely that the perceptions in villages upriver are magnified by a stronger cultural attachment to thatch palm as a resource shaping identity, social relations, and local economies.

These results reflect the multifaceted and complex nature of local perceptions, interweaving the roles of culture, power, and history in understanding resource change, but at the same time, lead us to an important question. Have the people in the villages upriver really perceived such a great change in thatch palm? Table 2 shows the people in villages upriver reported that the walking distance to the thatch palm groves has increased as much as $3.28 \pm 1.90$ $\mathrm{km}$ in the last 30 years. However, in most of these villages, thatch palm groves are to be found nowadays within $3 \mathrm{~km}$ of the human settlements (Fig. 2). Thus, according to locals, somewhere in the past, thatch palm would have been abundant in the vicinity of villages (i.e., less than $0.5 \mathrm{~km}$ ) in places other than the upper flank of ridges, which is apparently inconsistent with the ecological distribution of the species (Moraes 1999, Ergueta et al. 2006). A possible explanation for this misfit could be that the perceptions of people upriver are partially shaped by the resource trajectories undergone in villages closer to the market town, where the change seems to have been more critical. Ethnographic evidence shows that Tsimane' people travel frequently along the Maniqui River, generally to visit kin (Reyes-García and TAPS 2012). In this context, it is likely that Tsimane' people from villages closer to town might have transferred their change perceptions to the villagers from upriver who, in turn, might have internalized these perceptions as a threatening reality. 
Table 4. Definition and summary statistics of variables measuring behavior and perceptions in the two villages under study.

\begin{tabular}{|c|c|c|c|c|c|c|c|}
\hline \multirow[t]{2}{*}{ Variable type } & \multirow[t]{2}{*}{ Variable name } & \multirow[t]{2}{*}{ Description } & \multicolumn{2}{|c|}{$\begin{array}{c}\text { Village closer } \\
\text { to town }\end{array}$} & \multicolumn{2}{|c|}{$\begin{array}{l}\text { Village farther from } \\
\text { town }\end{array}$} & \multirow[t]{2}{*}{ T-test } \\
\hline & & & Mean & SE & Mean & $\mathrm{SE}$ & \\
\hline Availability & $\begin{array}{l}\text { Measured walking } \\
\text { distance }\end{array}$ & $\begin{array}{l}\text { Average measured walking distance to } \\
\text { the closest thatch palm grove }(\mathrm{km})\end{array}$ & 5.065 & 0.221 & 2.478 & 0.108 & 0.000 \\
\hline \multirow[t]{2}{*}{ Perception } & $\begin{array}{l}\text { Availability } \\
\text { perception }\end{array}$ & $\begin{array}{l}\text { Average perceived walking distance to } \\
\text { closest thatch palm grove }(\mathrm{km})\end{array}$ & 6.074 & 0.211 & 5.382 & 0.252 & 0.047 \\
\hline & Change perception & $\begin{array}{l}\text { Average perceived change of walking } \\
\text { distance to the closest thatch palm grove } \\
\text { over the respondent's lifetimes }(\mathrm{km})\end{array}$ & 4.321 & 0.234 & 4.104 & 0.266 & 0.538 \\
\hline \multirow[t]{2}{*}{ Harvesting behavior } & Panes & $\begin{array}{l}\text { Mean individual number of thatch palm } \\
\text { panes gathered in past two days (panes) }\end{array}$ & 2.622 & 0.421 & 5.355 & 0.661 & 0.001 \\
\hline & Productivity & $\begin{array}{l}\text { Average number of thatch palm panes } \\
\text { gathered per hour invested in past two } \\
\text { days (panes/hour) }\end{array}$ & 0.231 & 0.413 & 0.754 & 0.690 & 0.000 \\
\hline \multirow[t]{2}{*}{$\begin{array}{l}\text { Management } \\
\text { behavior }\end{array}$} & Rule compliance & $\begin{array}{l}\text { Average individual self-reported respect } \\
\text { of norms regulating thatch palm } \\
\text { gathering }(0-3)\end{array}$ & 0.365 & 0.073 & 1.133 & 0.137 & 0.000 \\
\hline & Involvement & $\begin{array}{l}\text { Average number of communal meetings } \\
\text { attended by an individual }(0-3)\end{array}$ & 1.904 & 0.153 & 2.355 & 0.199 & 0.071 \\
\hline
\end{tabular}

\section{Local harvesting and management behavior}

Table 4 shows significant differences in harvesting and management behavior between the two villages studied. In the village farther from town, locals tend to harvest significantly higher amounts of thatch palm compared with the village closer to town $(\mathrm{P}<0.01)$. Similarly, thatch palm harvesting productivity (panes/hour) is significantly higher in the village farther from town than in the village closer to town $(\mathrm{P}<0.01)$, where thatch palm is significantly less available, according to our ecological data $(\mathrm{P}<0.01)$. In contrast, rule compliance and involvement in informal institutions are significantly lower in the village closer to town than in the village farther from town ( $\mathrm{P}<0.01$ and $\mathrm{P}<0.1$, respectively), where despite the increased harvesting levels, there seems to be higher compliance with the Tsimane' management regime.

The fact that the management and harvesting behaviors are different in both villages is hardly surprising considering that the Tsimane' have been described as the indigenous group in Bolivia displaying the greatest variation in levels of both integration into the market economy and cultural change (Godoy et al. 2001). In line with what is put forward by Salo et al. (2013) for the use of palm leaves by different Amazonian groups, we found significant differences regarding the extent to which there are community agreements and norms governing thatch palm management, and whether or not these are being followed and respected (Table 4). A possible explanation for these differences may lie in the degree of market integration and its effects on eroding social capital (e.g., Basurto et al. 2013). In forest common-pool resources, market access has been found to reduce the durability of cooperative institutions for sustainable resource management (Young 1994, Agrawal 2001). Previous research among the Tsimane' has shown that integration into the market economy was negatively associated with investments in social capital; i.e., market economy promoting individualistic behaviors was found to be in detriment to prosocial behavior (Godoy et al. 2007, Gurven et al. 2008).
The results of the regressions of individual harvesting and management behavior against individual perceptions of $G$. deversa availability and change show some paradoxical findings (Table 5). In the village closer to town, we found (1) negative associations between harvesting proxies and availability perception ( $\mathrm{P}<0.001$ for panes and $\mathrm{P}<0.05$ for productivity) and (2) positive associations between harvesting proxies and change perception ( $\mathrm{P}<0.05$ for both). In the village farther from town, no significant relation was found between perceptions and harvesting behavior. However, in the village farther from town, we found (1) a positive association between involvement in informal institutions and availability perception $(\mathrm{P}<0.05)$ and (2) positive associations between our management behavior proxies and change perception $(\mathrm{P}<0.001$ and $\mathrm{P}<0.05$, respectively). Contrarily, no association was found between perceptions and management behavior in the village closer to town.

In the village farther from town, where thatch palm is still relatively available, individuals display more attachment to the informal regime for managing thatch palm, probably because they have greater personal incentives to do so. Because thatch palm is still relatively available in these villages, individuals perceive that by investing time and effort in managing the resource at present (e.g., complying with management norms or attending meetings), they can reap personal benefits in the future. In other terms, individual investments in sustainable management might reflect a person's desire to have a safety net for the future. In contrast, in the village closer to town, where one has to walk up to 5 hours round trip $(10.72 \mathrm{~km})$ to harvest thatch palm, the payoffs to collective action are probably perceived to be lower.

Our findings dovetail with the bulk of research examining time preferences among natural resource users (Alvard et al. 1997, Reyes-García et al. 2007). Studies worldwide have shown that individuals with high discount rates, i.e., unwilling to sacrifice short-term benefits for potentially higher gains in the future, tend 
Table 5. Results of ordinary least-square and Poisson multivariate regressions of different individual harvesting and social behavior variables against individual perceptions of Geonoma deversa availability and change.

\begin{tabular}{|c|c|c|c|c|c|}
\hline \multirow[t]{3}{*}{ Village } & \multirow[t]{3}{*}{ Explanatory variables } & \multicolumn{4}{|c|}{ Dependent variable $^{\dagger}$} \\
\hline & & \multicolumn{2}{|c|}{ Harvesting $^{\ddagger}$} & \multicolumn{2}{|c|}{ Management $^{\S}$} \\
\hline & & Panes & Productivity & Rule compliance & Involvement \\
\hline \multirow[t]{8}{*}{ Closer from town } & Availability perception & $-0.741(0.265)^{* * *}$ & $-0.097(0.042)^{* *}$ & $0.016(0.042)$ & $-0.012(0.054)$ \\
\hline & $\mathrm{N}$ & 52 & 52 & 52 & 52 \\
\hline & $\mathrm{R}^{2}$ & 0.234 & 0.116 & - & - \\
\hline & Wald $\mathrm{Chi}^{2}$ & - & - & 2.02 & 2.77 \\
\hline & Change perception & $0.596(0.242)^{* *}$ & $0.105(0.039)^{* *}$ & $0.024(0.041)$ & $0.034(0.050)$ \\
\hline & $\mathrm{N}$ & 52 & 52 & 52 & 52 \\
\hline & $\mathrm{R}^{2}$ & 0.210 & 0.153 & - & - \\
\hline & Wald Chi ${ }^{2}$ & - & - & 1.93 & 2.65 \\
\hline \multirow[t]{8}{*}{ Farther from town } & Availability perception & $-0.109(0.375)$ & $0.022(0.068)$ & $-0.033(0.027)$ & $-0.085(0.036)^{* *}$ \\
\hline & $\mathrm{N}$ & 45 & 45 & 45 & 45 \\
\hline & $\mathrm{R}^{2}$ & 0.087 & 0.060 & - & - \\
\hline & Wald $\mathrm{Chi}^{2}$ & - & - & 3.30 & 6.59 \\
\hline & Change perception & $0.125(0.391)$ & $-0.011(0.065)$ & $0.063(0.022)^{* * *}$ & $0.103(0.041)^{* *}$ \\
\hline & $\mathrm{N}$ & 45 & 45 & 45 & 45 \\
\hline & $\mathrm{R}^{2}$ & 0.088 & 0.058 & - & - \\
\hline & Wald $\mathrm{Chi}^{2}$ & - & - & 9.38 & 8.62 \\
\hline
\end{tabular}

${ }^{\dagger}$ Coefficient reported (standard error in parentheses); see Table 4 for definition of variables. No collinearity between variables (all Variance Inflation Factors (VIF) <1).

${ }^{\ddagger}$ For harvesting behavior variables, these correspond to OLS regression, including controls for age and sex, and clustering based on the household of the informant.

${ }^{\S}$ For management variables, these correspond to Poisson regressions, including controls for age and sex, and clustering based on the household of the informants.

${ }^{*}, * *$, and ${ }^{* * *}$, significant at $<0.1,<0.05$, and $<0.01$, respectively.

to have more impulsive behaviors and more often violate management regulations (Kirby et al. 2002, Akpalu 2008). However, this literature tends to neglect discount rates as largely contingent upon the perception of change in the availability of natural resources (Lu 2005, Suuronen et al. 2010). Studies on resource users' cooperative-behavior disposition have widely examined socioeconomic factors affecting prosocial behavior (e.g., Aswani et al. 2013, Teh et al. 2014), largely neglecting the role of perceptions of change and availability. Our research complements this body of literature by suggesting that perceptions of availability and change affect the benefits and costs of sustainably managing common-pool natural resources.

If the resource is already unavailable (e.g., village closer to town), the costs of organizing users to sustainably manage the resource might be perceived as unnecessarily high and unlikely to generate benefits. In contrast, such self-organization is likely to occur if the resource is still easily available, but only after the users have perceived some level of risk, e.g., observing substantial change in resource availability (Rudel et al. 2002, Potetee et al. 2010). Perceptions of resource change can therefore spark collective action for sustainable management (Ostrom 1999, Oldekop et al. 2012). The danger here, however, is that gradual changes in the availability of natural resources remain unnoticed to resource users until this availability is already severely compromised (Alessa et al. 2008, Fernández-Llamazares et al. 2015b).

Data obtained from our ethnographic observation methods provide evidence supporting our arguments. In the village closer to town, $G$. deversa is rarely a conversation topic; and when people are asked about it, they tend to feel quite hopeless about the state of the resource. Because $G$. deversa has become scarce, most people are not concerned with its management and it is largely considered a lost cause. Contrarily, in the village farther from town, several discussions to better regulate access and use of thatch palm groves were witnessed. For example, in communal meetings, thatch palm tends to be a burning issue, often raising lively discussion among local villagers. Local people often expressed concern about the status of the resource and a wish for improved management strategies. As one Tsimane' man reported in one of the communal meetings: "It is sad seeing how our thatch palm disappears and traders become rich, while we become poorer by losing our resources. We cannot allow that!" (man, age 33, April 2013).

\section{CONCLUSIONS}

We conclude by highlighting some implications of our findings. The literature on environmental perceptions has already stressed that accurate perceptions of resource availability and change hold potential for furnishing collective responses to ensure sustainable management (e.g., Oldekop et al. 2012, McCarthy et al. 2014). Our study challenges this body of literature by providing evidence that, regardless of whether local perceptions are accurate or not from an ecological standpoint, they are crucial in informing sustainable management of dwindling natural resources. It is clear that most of the harvesting and management actions that the Tsimane' undertake are, at least partially, shaped by local perceptions. Particularly in villages where claims over $G$. deversa unavailability were magnified, local perceptions seem to be an instrumental factor in ensuring collective action for its sustainable management. Such local perceptions reflect the multifaceted complexity of cognition and, arguably, provide a better picture of the historical context of the changes undergone than of their ecological nature and extent. 
Without denying the importance of accurately detecting, understanding, and interpreting gradual changes in the ecosystem, our results show that local perceptions play an important role in creating or blocking incentives for societal change and sustainable management of natural resources. In addressing the overharvesting of a natural resource, a better understanding of how local resource users perceive availability and change in the stock of these resources is critical. Local perceptions encompass cultural values, beliefs, and historical aspects that are essential for the endurance of any long-term sustainable management regime of natural resources.

Responses to this article can be read online at: http://www.ecologyandsociety.org/issues/responses. php/8092

\begin{abstract}
Acknowledgments:
The research leading to these results received funding from the European Research Council under the European Union's Seventh Framework Programme (FP7/2007-2013) / ERC grant agreement FP7-261971-LEK. AF-L, AP, and MC were also supported by the Academy of Finland (grant agreements 250444 and 257686), and AF- $L$ received additional support from the Finnish Centre for International Mobility (CIMO). We thank all the Tsimane' for their invaluable contributions to this project; the Gran Consejo Tsimane' and CBIDSI for all their support; V. Cuata, S. Fraixedas, S. Huditz, P. Pache, M. Pache, and I. V. Sánchez for all their help during fieldwork; A. C. Luz and J. Nyman for cartographical assistance; and M. McBride for insightful comments and ideas.
\end{abstract}

\section{LITERATURE CITED}

Agrawal, A. 2001. Common property institutions and sustainable governance of resources. World Development 29:1649-1672. http://dx.doi.org/10.1016/S0305-750X(01)00063-8

Akpalu, W. 2008. Fishing regulations, individual discount rate, and fisherman behaviour in a developing country fishery. Environment and Development Economics 13:591-606.

Alessa, L. N., A. A. Kliskey, P. Williams, and M. Barton. 2008. Perception of change in freshwater in remote resource-dependent Arctic communities. Global Environmental Change 18:153-164. http://dx.doi.org/10.1016/j.gloenvcha.2007.05.007

Alvard, M. S., J. G. Robinson, K. H. Redford, and H. Kaplan. 1997. The sustainability of subsistence hunting in the neotropics. Conservation Biology 11:977-982. http://dx.doi.org/10.1046/ j.1523-1739.1997.96047.x

Aswani, S., G. G. Gurney, S. Mulville, J. Matera, and M. Gurven. 2013. Insights from experimental economics on local cooperation in a small-scale fishery management system. Global Environmental Change 23:1402-1409. http://dx.doi.org/10.1016/j. gloenvcha.2013.08.003

Barthel, S., C. Folke, and J. Colding. 2013. Social ecological memory in urban gardens - retaining the capacity for the management of ecosystem services. Global Environmental Change 20:255-265. http://dx.doi.org/10.1016/j.gloenvcha.2010.01.001
Basurto, X., A. Bennett, A. Hudson Weaver, S Rodriguez-Van Dyck, and J.-S. Aceves-Bueno. 2013. Cooperative and noncooperative strategies for small-scale fisheries' selfgovernance in the globalization era: implications for conservation. Ecology and Society 18(4):38. http://dx.doi. org/10.5751/ES-05673-180438

Berkes, F. 2009. Indigenous ways of knowing and the study of environmental change. Journal of the Royal Society of New Zealand 39:151-156. http://dx.doi.org/10.1080/03014220909510568

Berkes, F., J. Colding, and C. Folke. 2000. Rediscovery of traditional ecological knowledge as adaptive management. Ecological Applications 10:1251-1262. http://dx.doi.org/10.1890/1051-0761 (2000)010[1251:ROTEKA]2.0.CO;2

Bodin, Ö., and B. I. Crona. 2008. Management of natural resources at the community level: exploring the role of social capital and leadership in a rural fishing community. World Development 36:2763-2779. http://dx.doi.org/10.1016/j. worlddev.2007.12.002

Chazdon, R. L. 1991. Effect of leaf and ramet removal on growth and reproduction of Geonoma congesta, a clonal understorey palm. Journal of Ecology 79:1137-1146. http://dx.doi. org/10.2307/2261104

Ergueta, P., C. Otterburg, and S. Estenssoro. 2006. Jatata: un recurso valioso para los habitantes del bosque tropical. MacArthur Foundation and Trópico, La Paz, Bolivia.

Fazey, I., J. A. Fazey, and D. M. A. Fazey. 2005. Learning more effectively from experience. Ecology and Society 10(2):4. [online] URL: http://www.ecologyandsociety.org/vol10/iss2/art4/

Fernández-Llamazares, Á., I. Díaz-Reviriego, A. C. Luz, M. Cabeza, A. Pyhälä, and V. Reyes-García. 2015b. Rapid ecosystem change challenges the adaptive capacity of local environmental knowledge. Global Environmental Change 31:272-284. http://dx. doi.org/10.1016/j.gloenvcha.2015.02.001

Fernández-Llamazares, Á., I. Díaz-Reviriego, and I. V. Sánchez. 2014. Las voces del cambio: percepciones de una sociedad ante el proceso de cambio. Pages 355-380 in V. Reyes-García and T. Huanca, editors. Cambio global, cambio local. La sociedad Tsimane' ante la globalización. Icaria Editorial, Barcelona, Spain.

Fernández-Llamazares, Á., M. E. Méndez-López, I. DíazReviriego, M. F. McBride, A. Pyhälä, A. Rosell-Melé, and V. Reyes-García. 2015a. Links between media communication and local perceptions of climate change in an indigenous society. Climatic Change 131:307-320. http://dx.doi.org/10.1007/ s10584-015-1381-7

Gagnon, C. A., and D. Berteaux. 2009. Integrating traditional ecological knowledge and ecological science: a question of scale. Ecology and Society 14(2):19. [online] URL: http://www. ecologyandsociety.org/vol14/iss2/art19/

Garibaldi, A., and N. Turner. 2004. Cultural keystone species: implications for ecological conservation and restoration. Ecology and Society 9(3):1. [online] URL: http://www.ecologyandsociety. org/vol9/iss $3 /$ art1/

Gearheard, S., M. Pocernich, R. Stewart, J. Sanguya, and H. P. Huntington. 2010. Linking Inuit knowledge and meteorological 
station observations to understand changing wind patterns at Clyde River, Nunavut. Climatic Change 100:267-294. http://dx. doi.org/10.1007/s10584-009-9587-1

Godoy, R., K. N. Kirby, and D. Wilkie. 2001. Tenure security, private time preference, and use of natural resources among lowland Bolivian Amerindians. Ecological Economics 38:105-118. http://dx.doi.org/10.1016/S0921-8009(01)00144-6

Godoy, R., V. Reyes-García, T. Huanca, W. R. Leonard, R. G. Olvera, J. Bauchet, Z. Ma, J. St. John, M. Miodowski, O. Zapata Ríos, V. Vadez, and C. Seyfried. 2007. The role of community and individuals in the formation of social capital. Human Ecology 35:709-721. http://dx.doi.org/10.1007/s10745-006-9106-1

Guèze, M., A. C. Luz, J. Paneque-Gálvez, M. J. Macía, M. OrtaMartínez, J. Pino, and V. Reyes-García. 2014a. Are ecologically important tree species the most useful? A case study from indigenous people in the Bolivian Amazon. Economic Botany 68:1-15. http://dx.doi.org/10.1007/s12231-014-9257-8

Guèze, M., J. Paneque-Gálvez, and A. C. Luz. 2014b. El ambiente natural y la degradación forestal. Pages 65-89 in V. Reyes-García and T. Huanca, editors. Cambio global, cambio local. La sociedad Tsimane' ante la globalización. Icaria Editorial, Barcelona, Spain.

Gurven, M., A. Zanolini, and E. Schniter. 2008. Culture sometimes matters: intra-cultural variation in pro-social behaviour among Tsimane Amerindians. Journal of Economic Behavior \& Organization 67:587-607. http://dx.doi.org/10.1016/j. jebo.2007.09.005

Houde, N. 2007. The six faces of traditional ecological knowledge: challenges for Canadian co-management arrangements. Ecology and Society 12(2):34. [online] URL: http://www.ecologyandsociety. org/vol12/iss $2 /$ art $34 /$

Huanca, T. 2008. Tsimane' oral tradition, landscape and identity in tropical forest. Imprenta Wagui, La Paz, Bolivia.

Ingold, T., and T. Kurttila. 2000. Perceiving environment in Finnish Lapland. Body \& Society 6:183-196. http://dx.doi. org/10.1177/1357034X00006003010

Kirby, K. N., R. Godoy, V. Reyes-García, E. Byron, L. Apaza, W. Leonard, E. Pérez, V. Vadez, and D. Wilkie. 2002. Correlates of delay-discount rates: evidence from Tsimane' Amerindians of the Bolivian rain forest. Journal of Economic Psychology 23:291-316. http://dx.doi.org/10.1016/S0167-4870(02)00078-8

Leclerc, C., C. Mwongera, P. Camberlin, and J. Boyard-Micheau. 2013. Indigenous past climate knowledge as a cultural built-in object and its accuracy. Ecology and Society 18(4):22. http://dx. doi.org/10.5751/ES-05896-180422

López-Hoffman, L., I. E. Monroe, E. Narváez, M. MartínezRamos, and D. D. Ackerly. 2006. Sustainability of mangrove harvesting: how do harvesters' perceptions differ from ecological analysis? Ecology and Society 11(2):14. [online] URL: http://www. ecologyandsociety.org/vol11/iss2/art14/

Lu, F. E. 2001. The common property regime of the Huaroani Indians of Ecuador: implications and challenges to conservation. Human Ecology 29:425-447. http://dx.doi.org/10.1023/A:1013193821187

Lu, F. 2005. The Catch-22 of conservation: indigenous peoples, biologists and cultural change. Human Ecology 33:200-215.
Luz, A. C. 2013. The role of acculturation in indigenous people's hunting patterns: implications for wildlife conservation. The case of the Tsimane' in the Bolivian Amazon. Dissertation. Autonomous University of Barcelona, Barcelona, Spain.

Maule, A. J., and G. P. Hodgkinson. 2002. Heuristics, biases and strategic decision making. Psychologist 15:68-71.

McCarthy, A., C. Hepburn, N. Scott, K. Schweikert, R. Turner, and H. Moller. 2014. Local people see and care most? Severe depletion of inshore fisheries and its consequences for Mãori communities in New Zealand. Aquatic Conservation: Marine and Freshwater Ecosystems 24:369-390. http://dx.doi.org/10.1002/ aqc. 2378

Moller, H., F. Berkes, P. O. Lyver, and M. Kislalioglu. 2004. Combining science and traditional ecological knowledge: monitoring populations for co-management. Ecology and Society 9(3):2. [online] URL:http://www.ecologyandsociety.org/vol9/ iss $3 / \operatorname{art} 2 /$

Moraes, M. 1999. Richness and utilization of palms in Boliviasome essential criteria for their management. Pages 269-288 in W. Barthlott and M. Winiger, editors. Biodiversity - a challenge for development research and policy. Springer Verlag, Heidelberg, Germany.

Noss, A. J., I. Oetting, and R. L. Cuéllar. 2005. Hunter selfmonitoring by the Isoseño-Guaraní in the Bolivian Chaco. Biodiversity \& Conservation 14:2670-2693. http://dx.doi. org/10.1007/s10531-005-8401-2

Oldekop, J. A., A. J. Bebbington, N. K. Truelove, G. Holmes, S. Villamarín, and R. F. Preziosi. 2012. Environmental impacts and scarcity perception influence local institutions in indigenous Amazonian Kichwa communities. Human Ecology 40:101-115. http://dx.doi.org/10.1007/s10745-011-9455-2

Orlove, B., C. Roncoli, M. Kabugo, A. Majugu. 2010. Indigenous climate knowledge in southern Uganda: the multiple components of a dynamic regional system. Climatic Change 100:243-265. http://dx.doi.org/10.1007/s10584-009-9586-2

Ostrom, E. 1990. Governing the commons: the evolution of institutions for collective action. Cambridge University Press, Cambridge, UK. http://dx.doi.org/10.1017/CBO9780511807763

Ostrom, E. 1999. Self-governance and forest resources. CIFOR Occasional Paper No. 20. Center for International Forestry Research, Bogor, Indonesia. http://dx.doi.org/10.17528/cifor/000536

Ostrom, E. 2008. The challenge of common-pool resources. Environment: Science and Policy for Sustainable Development 50:8-21. http://dx.doi.org/10.3200/envt.50.4.8-21

Paniagua-Zambrana, N. 2005. Diversidad, densidad, distribución y uso de palmas en la región del Madidi, noroeste del departamento de La Paz (Bolivia). Ecología en Bolivia 40:265-280.

Pauly, A. 1928. Ensayo de etnografia Americana. Viajes y exploraciones. Casa Jacobo Peuser, Buenos Aires, Argentina.

Peres, C. A. 2000. Effects of subsistence hunting on vertebrate community structure in Amazonian forests. Conservation Biology 14:240-253. http://dx.doi.org/10.1046/j.1523-1739.2000.98485.x 
Peres, C. A. 2010. Overexploitation. Pages 107-130 in N. S. Sodhi and P. R. Ehrlich, editors. Conservation biology for all. Oxford University Press, Oxford, UK. http://dx.doi.org/10.1093/acprof: oso/9780199554232.003.0007

Potetee, A., M. A. Janssen, and E. Ostrom. 2010. Working together: collective action, the commons, and multiple methods in practice. Princeton University Press, Princeton, New Jersey, USA. http://dx.doi.org/10.1515/9781400835157

Raymond, C. M., I. Fazey, M. S. Reed, L. C. Stringer, G. M. Robinson, and A. C. Evely. 2010. Integrating local and scientific knowledge for environmental management. Journal of Environmental Management 91:1766-1777. http://dx.doi.org/10.1016/ j.jenvman.2010.03.023

Reyes-García, V. 2001. Indigenous people, ethnobotanical knowledge, and market economy. A case study of the Tsimane' Amerindians, Bolivia. Dissertation. University of Florida, Gainesville, Florida, USA.

Reyes-García, V., R. Godoy, T. Huanca, W. R. Leonard, T. W. McDade, S. Tanner, and V. Vadez. 2007. The origins of monetary income inequality: patience, human capital, and the division of labor. Evolution \& Human Behavior 28:37-47. http://dx.doi. org/10.1016/j.evolhumbehav.2006.07.001

Reyes-García, V., R. A. Godoy, V. Vadez, I. Ruiz-Mallén, T. Huanca, W. R. Leonard, T. W. McDade, S. Tanner, and TAPS Bolivian Study Team. 2009. The pay-offs to sociability. Do solitary and social leisure relate to happiness? Human Nature 20:431-446. http://dx.doi.org/10.1007/s12110-009-9073-5

Reyes-García, V., J. C. Ledezma, J. Paneque-Gálvez, M. Orta, M. Gueze, A. Lobo, D. Guinart, and A. C. Luz. 2012. Presence and purpose of nonindigenous peoples on indigenous lands: a descriptive account from the Bolivian lowlands. Society \& Natural Resources 25:270-284. http://dx.doi.org/10.1080/08941920.2010.531078

Reyes-García, V., J. Paneque-Gálvez, P. Bottazzi, A. C. Luz, M. Gueze, M. J. Macía, M. Orta-Martínez, and P. Pacheco. 2014. Indigenous land reconfiguration and fragmented institutions: a historical political ecology of Tsimane' lands (Bolivian Amazon). Journal of Rural Studies 34:282-291. http://dx.doi.org/10.1016/j. jrurstud.2014.02.007

Reyes-García, V., and Tsimane' Amazonian Panel Study (TAPS). 2012. Happiness in the Amazon: folk explanations of happiness in a hunter-horticulturalist society in the Bolivian Amazon. Pages 209-225 in H. Selin and G. Davey, editors. Happiness across cultures. Springer, Heidelberg, Germany. http://dx.doi. org/10.1007/978-94-007-2700-7_15

Riester, J. 1993. Universo mítico de los chimane. Pueblos indígenas de las tierras bajas de Bolivia. Apoyo Para el Campesino-Indígena del Oriente Boliviano, Santa Cruz de la Sierra, Bolivia.

Riseth, J. A., H. Tømmervik, E. Helander-Renvall, N. Labba, C. Johansson, E. Malnes, J. W. Bjerke, C. Jonsson, V. Pohjola, L.-E. Sarri, A. Schanche, and T. V. Callaghan. 2011. Sámi traditional ecological knowledge as a guide to science: snow, ice and reindeer pasture facing climate change. Polar Record 47:202-217. http:// dx.doi.org/10.1017/S0032247410000434
Rist, J., E.J. Milner-Gulland, G. Cowlishaw, and M. Rowcliffe. 2010. Hunter reporting of catch per unit effort as a monitoring tool in bushmeat-harvesting system. Conservation Biology 24:489-499. http://dx.doi.org/10.1111/j.1523-1739.2010.01470.x

Rudel, T. K., D. Bates, and R. Machinguiashi. 2002. Ecologically noble Amerindians? Cattle ranching and cash cropping among Shuar and colonists in Ecuador. Latin American Research Review 37:144-159.

Salo, M., A. Sirén, and R. Kalliola. 2013. Palm leaves, sustainability and dignity. Pages 125-141 in M. Salo, A. Sirén, and R. Kalliola, editors. Diagnosing wild species harvest. Elsevier, London, UK. http://dx.doi.org/10.1016/b978-0-12-397204-0.00007-3

Sirén, A. 2006. Natural resources in indigenous peoples' land in Amazonia: a tragedy of the commons? International Journal of Sustainable Development \& World Ecology 13:363-374. http://dx. doi.org/10.1080/13504500609469686

StataCorp. 2011. Stata Statistical Software, Release 12. College Station, Texas, USA.

Suuronen, P., P. Jounela, and V. Tschernij. 2010. Fishermen responses on marine protected areas in the Baltic cod fishery. Marine Policy 34:237-243. http://dx.doi.org/10.1016/j.marpol.2009.07.001

Swezey, S. L., and R. F. Heizer. 1977. Ritual management of salmonid fish resources in California. Journal of California Anthropology 4:6-29.

Teh, L. S. L., L. C. L. Teh, and U. R. Sumaila. 2014. Time preference of small-scale fishers in open access and traditionally managed reef fisheries. Marine Policy 44:222-231. http://dx.doi. org/10.1016/j.marpol.2013.08.028

Verweij, M. C., W. L. T. van Densen, and A. J. P. Mol. 2010. The tower of Babel: different perceptions and controversies on change and status of North Sea fish stocks in multi-stakeholder settings. Marine Policy 34:522-533. http://dx.doi.org/10.1016/j.marpol.2009.10.008

Yeh, E. T. 2015. 'How can experience of local residents be "knowledge"?' Challenges in interdisciplinary climate change research. Area (Early View) http://dx.doi.org/10.1111/area.12189

Young, K. R. 1994. Roads and the environmental degradation of tropical montane forests. Conservation Biology 8:972-976. http:// dx.doi.org/10.1046/j.1523-1739.1994.08040972.x 
Appendix 1. Thatch palm questionnaires used in the interviews with local villagers.

\begin{tabular}{|c|c|c|c|}
\hline Aim & Method & Question & Coding format \\
\hline $\begin{array}{l}\text { Ethnographic } \\
\text { description of the } \\
\text { Tsimane' } \\
\text { management } \\
\text { regime of } G \text {. } \\
\text { deversa }\end{array}$ & $\begin{array}{l}\text { Open-ended } \\
\text { interviews } \\
\text { (in the } \\
\text { thatch palm } \\
\text { groves) }\end{array}$ & $\begin{array}{l}\text { Is it possible to harvest any palm thatch that you find in the forest? Why/Why not? } \\
\text { Does each family in your community have a palm thatch grove where they usually harvest thatch palm? How do you } \\
\text { decide that a thatch palm grove belongs to a particular family? } \\
\text { Do you leave some thatch palm groves aside so that they can grow? } \\
\text { In your thatch palm grove, do you harvest as much thatch palm as you want? Are there any restrictions as to how much } \\
\text { thatch palm you can harvest? Which are these restrictions? } \\
\text { In the palm thatch grove where you usually harvest thatch palm, do people from other households harvest? } \\
\text { Do people from other communities come and harvest palm thatch in your community? Is that OK with you? } \\
\text { Do you go to other communities to harvest palm thatch? } \\
\text { Did you ever have some conflict/problem with someone with regard to palm thatch harvesting? }\end{array}$ & Text \\
\hline $\begin{array}{l}\text { Measurement of } \\
\text { local perceptions } \\
\text { of } G \text {. deversa } \\
\text { change and } \\
\text { availability }\end{array}$ & $\begin{array}{l}\text { Focus group } \\
\text { discussions }\end{array}$ & $\begin{array}{l}\text { How much time do you have to walk to reach the closest thatch palm grove in your community nowadays? } \\
\text { When you were a kid, how much did you use to walk to reach the closest thatch palm grove in your community? } \\
\text { Who is the owner of the thatch palm groves in the village? } \\
\text { Are there currently any restrictions for the local peoples to harvest thatch palm? } \\
\text { Are you allowed to sell/trade thatch palm? } \\
\text { How do you trade it? Do you change it to the merchant for goods or do you sell it directly in town? } \\
\text { For outsiders, are there currently any restrictions for the harvesting of thatch palm? } \\
\text { If any outsider wants to come and harvest thatch palm, is it possible? } \\
\text { Do they have to ask any permission? To whom? } \\
\text { Are there currently any outsiders harvesting thatch palm in your village? How many? } \\
\text { Do you think that the thatch palm traders respect the Tsimane' traditional way of harvesting? } \\
\text { When did the first thatch palm traders arrive to this area? } \\
\text { Compared to when you were a kid, do you think that nowadays thatch palm within the limits of your community is } \\
\text { more/same/less abundant than before? Why? }\end{array}$ & $\begin{array}{l}\text { Minutes } \\
\text { Minutes }\end{array}$ \\
\hline \multirow{2}{*}{$\begin{array}{l}\text { Measurement of } \\
\text { the behavior } \\
\text { regarding } G \text {. } \\
\text { deversa } \\
\text { harvesting and } \\
\text { management }\end{array}$} & $\begin{array}{l}\text { Scan } \\
\text { observations }\end{array}$ & $\begin{array}{l}\text { How much thatch palm did you bring from the forest in the previous two days? } \\
\text { How many hours did you spend harvesting thatch palm in the previous two days? }\end{array}$ & $\begin{array}{l}\text { Nr of panes } \\
\text { Hours }\end{array}$ \\
\hline & $\begin{array}{l}\text { Semi- } \\
\text { structured } \\
\text { interviews }\end{array}$ & $\begin{array}{l}\text { Do you usually harvest thatch palm mother plants? } \\
\text { Are there places in your community where you know that you cannot harvest any palm thatch? } \\
\text { Do you go harvest thatch palm from thatch palm groves owned by other families? } \\
\text { (Observed) attendance to the three last meetings held in the village }\end{array}$ & $\begin{array}{l}1=\text { no } / 0=\text { yes } \\
1=\text { yes } / 0=\text { no } \\
1=\text { yes } / 0=\text { no } \\
\text { Nr of meetings } \\
\text { attended }(0-3)\end{array}$ \\
\hline
\end{tabular}


Appendix 2. List of villages sampled and corresponding characteristics along the Tsimane' Territory, Bolivian Amazonia.

\begin{tabular}{|c|c|c|c|c|c|c|c|c|c|c|c|c|}
\hline \multirow[t]{2}{*}{ Village } & \multirow[t]{2}{*}{$\begin{array}{l}\text { Number of } \\
\text { informants }\end{array}$} & \multirow[t]{2}{*}{$\begin{array}{l}\text { Distance } \\
\text { to market } \\
\text { town } \\
(\mathrm{km}) \dagger\end{array}$} & \multirow[t]{2}{*}{$\begin{array}{l}\text { Old- } \\
\text { growth } \\
\text { forest } \\
\left(\mathrm{km}^{2}\right)+\end{array}$} & \multirow[t]{2}{*}{$\begin{array}{l}\text { Elevation } \\
\text { (m.a.s.1.) }\end{array}$} & \multirow[t]{2}{*}{$\begin{array}{l}\text { Annual } \\
\text { precipitation } \\
(\mathrm{mm}) \S\end{array}$} & \multirow[t]{2}{*}{$\begin{array}{l}\text { Number } \\
\text { of visits } \\
\text { by thatch } \\
\text { palm } \\
\text { traders in } \\
\text { the past } \\
\text { month | }\end{array}$} & \multicolumn{2}{|c|}{$\begin{array}{l}\text { Average measured } \\
\text { walking distance to } \\
\text { the closest thatch } \\
\text { palm grove }(\mathrm{km})\end{array}$} & \multicolumn{2}{|c|}{$\begin{array}{l}\text { Average } \\
\text { perceived } \\
\text { walking } \\
\text { distance to the } \\
\text { closest thatch } \\
\text { palm grove } \\
(\mathrm{km})\end{array}$} & \multicolumn{2}{|c|}{$\begin{array}{l}\text { Average } \\
\text { perceived } \\
\text { change of } \\
\text { walking } \\
\text { distance to the } \\
\text { closest thatch } \\
\text { palm grove } \\
(\mathrm{km})\end{array}$} \\
\hline & & & & & & & Mean & SD & Mean & SD & Mean & SD \\
\hline 1 & 53 & 32.93 & 6.87 & 242 & 1868 & 6 & 5.065 & 0.221 & 6.074 & 1.538 & 4.321 & 0.234 \\
\hline 2 & 26 & 38.89 & 6.81 & 236 & 1891 & 5 & 6.801 & 0.297 & 6.525 & 1.331 & 4.695 & 1.439 \\
\hline 3 & 17 & 50.43 & 6.69 & 241 & 1912 & 3 & 6.641 & 0.290 & 6.745 & 1.521 & 2.684 & 1.225 \\
\hline 4 & 21 & 58.62 & 5.99 & 247 & 1931 & 5 & 5.718 & 0.250 & 5.330 & 1.319 & 2.823 & 0.648 \\
\hline 5 & 20 & 68.31 & 7.02 & 253 & 1962 & 3 & 4.023 & 0.176 & 4.836 & 1.434 & 2.964 & 1.642 \\
\hline 6 & 19 & 81.85 & 6.28 & 259 & 1991 & 3 & 3.874 & 0.169 & 4.187 & 0.593 & 2.484 & 1.042 \\
\hline 7 & 13 & 93.12 & 6.68 & 264 & 2013 & 3 & 3.364 & 0.147 & 3.960 & 0.761 & 2.484 & 1.188 \\
\hline 8 & 18 & 99.05 & 7.30 & 262 & 2028 & 4 & 2.798 & 0.122 & 4.702 & 2.817 & 2.611 & 2.789 \\
\hline 9 & 20 & 102.80 & 7.26 & 267 & 2042 & 5 & 3.837 & 0.168 & 4.017 & 1.432 & 2.588 & 1.317 \\
\hline 10 & 20 & 112.78 & 7.23 & 277 & 2069 & 4 & 2.675 & 0.117 & 4.797 & 1.465 & 3.568 & 1.351 \\
\hline 11 & 20 & 114.89 & 7.29 & 268 & 2062 & 4 & 1.646 & 0.072 & 5.031 & 1.659 & 2.164 & 1.484 \\
\hline 12 & 13 & 119.45 & 7.21 & 270 & 2074 & 7 & 1.208 & 0.053 & 5.760 & 2.161 & 3.900 & 2.212 \\
\hline 13 & 45 & 122.88 & 7.16 & 275 & 2091 & 4 & 2.478 & 0.108 & 5.383 & 1.692 & 4.104 & 0.266 \\
\hline
\end{tabular}

$\dagger$ Accounting for river meanders; $\$$ Estimations based on Landsate imagery for the year 2009, by applying a $5 \mathrm{~km}$ circular buffer to the center of each community (Luz 2013 ); $\S$ Estimations obtained from Worldclim dataset; | Report from the village leader ('corregidor') with information triangulated by other 2 village key informants. 